\title{
Analysis of Development Tendency of Public Administration Reform of Countries in Transition
}

\author{
Ya Chen \\ China West Normal University, Nanchong, 637002, China
}

Key words: Countries in transition, Public administration, Reform

\begin{abstract}
So-called countries in transition refer to the countries which are or have been transformed to market economy from original economic form like China, Vietnam and some Eastern European countries. Social economic form alters. This means national development in various aspects should be adjusted correspondingly. In particular, public administration should be adjusted. National transition is faced with transformation to democratic form the public can participate in from previous form. Besides, on this basis, governance system perfection should be conducted by regarding national citizens as the center. Some popular political campaigns and development may happen in transitional countries. These phenomena will result in challenges to democratic quality of public administration of countries in transition, make public administration revitalized and public management amended. This paper will analyze challenges faced by public administration reform of countries in transition, and then study the development tendency.
\end{abstract}

\section{Introduction}

Although there are numerous countries in transition in the world, their types and modes are diverse, such as South European mode and East Asian mode. However, the concept of countries in transition as described above mentions countries in transition studied in this paper mainly refer to the countries in transition formed after the collapse of the Soviet Union, or the countries which are or have been transformed to market economic form like China and Vietnam. So, this paper will adopt some special research methods (such as focus path) to describe contents of national public administration and great practical problems.

Public administration reform not just causes certain influence on public management, but also influences the relationship between the markets of countries in transition and governments and the relationship between the government and citizens. Most important of all, it generates certain influence on the markets of countries in transition, society and relations among countries, and their relations are reorganized. But, the purpose and connotation of public administration system do not aim to serve national administrative units and public sectors. Its most important purpose is to exert an effect on welfare of the whole country and play an important role in it.

\section{Challenges faced by public administration reform of countries in transition}

\section{How to take count of equity and efficiency simultaneously}

Due to the influence of functions and connotation of public administration, the working system also has political color. When studying public administration, we must know who can gain benefits from the system and what they gain ${ }^{[1]}$. Because after countries in transition are transformed, national economic form has become market economy. Hence, under such economic form, diverse interest groups will form. These interest groups want to express their demands and decisions, so they need a channel for expression. To meet their demand, the state or the government must attach more importance to democratic politics construction and social management. The democratic politics is to make the government establish a department or organization which can represent each interest group to pursue interest. Public administration should be such a department. Thus, the government must make sure measures or solutions taken by public administrative department must be fair, just and objective. This can guarantee to conform to democratic norms of countries in transition, help the citizens solve problems and reach common public interest. 
When the government handles various affairs, various departments including public administration must ensure fairness. Thus, citizens must undertake certain individual responsibilities, while the government also should satisfy citizens' needs and guarantee their interest. But countries in transition should not merely take into account of fairness principle, but also improve problem solving efficiency in administrative reform. Hence, there are numerous complex effects.

\section{How to balance dominance and public participation}

Although public administration connotation of countries in transition is democratization, this tendency is not changeless in the process of public administration democratization. Since economic mode of countries in transition has become market economy, economic change will certainly give rise to certain influence on social force. Then, a new social force will form. This new social force will be bound to express its political interest.

When national public administrative department makes decisions on relevant affairs and work and execute the work and affairs, it is not always limited to the elites of public administration. During implementing relevant public administration work, the most important work content is to coordinate with public relations and carry out wide public dialogues. Relevant workers or officers of public administrative department in countries in transition should regard serving citizens as the duty and lay the emphasis on maintaining citizen's basic benefits, instead of influencing government's development direction or providing support for government's development. Its connotation should be public organization with perfect integration force which can make positive response. But whether the final decision can be executed, this depends on national and government's provisions.

In current social development, relevant public policies made by public administrative department will generally involve interest of multiple parties. So, national political leaders should explicitly and actively express to enhance citizens' sense of responsibility so as to make groups or individuals participate in protection of citizen's interest.

\section{How to rationally distribute political rights}

In general, all consider political rights should belong to a state or a government. In 1940s, foreign scholars proposed "the lifeline of public administration is power". Thus, how to rationally distribute political rights is very significant for national public administration work[2]. In a diversified society, public administration acts on balancing rights of various social forces. Political rights are not only related to the degree of fusion between a country and the society, but also closely related to the degree of public participation in national administration and national administration ability.

In such circumstance, executive power of the government of countries in transition must be changed correspondingly in combination of multiple conditions. Public administration of countries in transition can exert its function only through knowing administrative power results, reforming national administrative power and achieving rational, scientific and legal power division.

\section{Development tendency of public administration reform of countries in transition}

When a country is transformed, its economic system should be correspondingly reformed in order to make the country develop more rapidly and be governed more perfectly, and to achieve social, economic and political development goal. In this process, it is also required to protect citizen's interest and realize national and social democratization. Thus, public administration of countries in transition must be correspondingly reformed and innovated. An important mission of public administration work is to create conditions for national and citizens' interest, instead of purely serving national administrative department. So, public administration reform development tendency of countries in transition should be responsibility enhancement, development of administrative technology and privatization development.

\section{Enhance public administration service features}

Economic form of countries in transition has changed to market economic mode from original economic mode. Since great change and development have happened to social environment and 
economic form, the requirements of national citizens for public services will be higher and higher. They require public services to meet work and high efficiency etc. Such phenomenon reflects national public administration has started to transform to service connotation ${ }^{[3]}$. As mentioned above, national public administrative department does not serve the government, but exists for the public. Hence, the public are the objects of administrative service, while administrative service is the essence of government. Public administration of countries in transition starts to place service in a low position, but pays more attention to governance. Besides, national administrative work was government-centered in the fast. But now, public administration of countries in transition starts to regard meeting public needs as the work emphasis. If national public administration can adopt good measurement means and perfect training system, bureaucratic culture may be changed. Besides, managers' leadership can be enhanced on the basis of altering career path prospect, and citizens' campaign can be more transparent.

\section{Enhance democratization features of public administration}

As national economic form begins to alter, the function of market economy has gone deep into various aspects of society and country. Thus, national citizens often participate in organizing and managing public administration work and the participation function becomes increasingly strong. In policy formulation and execution, the activities the public participate in also become more and more $^{[4]}$. Since such phenomena become more and more, the government must frequently contact citizens or the organizations formed by the citizens in public administration work. In addition, the government also should manage some daily work and affairs together with citizens. Public managers of government must confront such environment. However, current public managers are faced with a plight: although citizens more and more participate in public affairs, there is no fixed standard. In addition, the government should guarantee efficiency and accuracy of public affairs on the basis of ensuring citizens' participation degree. There are many democratization forms of public affairs. According to the scale, democratization forms can be classified into multiple types. All these should achieve internal participation of citizens and make sure administrative work is legal.

Citizens more and more participate in government's administrative management, and participation forms become increasingly mature. In such conditions, the relationship between public administration managers and citizens starts to mitigate, but managers also own essential power when making decisions on public affairs. If government's public administration can formulate an effective system of citizens' participation, the efficiency of public administration work can be promoted and the result effectiveness can be ensured.

\section{Enhance transnationalization feature of public administration}

In social development process, public administration work is usually regarded as national internal work and belongs to national public affair category. However, as society and era change continuously, public administration is not merely national internal affair ${ }^{[5]}$. Public administration affairs and decisions of countries in transition do not cover globalization problem in national affair and problem governance scope. But, social and national development requires giving sufficient attention to globalization problem, and globalization development will influence all kinds of affairs and work of each country. So, continuous development of globalization makes public administration of countries in transition start to accord with globalization course. National public administration affairs start to contain transnational contents and are not limited to a country. In such condition and environment, transnational administration appears. So-called transnational administration requires the countries which are under transition or have been transformed must divide some political work to corresponding international organizations.

\section{Enhance responsibility feature of public administration}

Social development and economic progress make various aspects of countries in transition must be reformed and updated correspondingly. Meanwhile, higher requirements are put forward for national public administration and work responsibility. Therefore, the country and government have great responsibilities for administrative work. Meanwhile, administrative work starts to become more 
complex. Nowadays, the society of countries in transition starts to become diversified, and social development also becomes modern. Hence, these have significant effects on administrative work of countries in transition. These effects are reflected in three aspects: public administration work owns political feature; public administration workers no longer play the role of citizens; public administration workers must manage different benefits. On this basis, public administration workers of countries in transition should strictly abide by social fairness principle in order to carry out effective handling and decision making according to interests of each aspect and meet various demands of citizens in countries in transition on the basis of rational solution of public administration affairs. Since national citizens have individuality, citizens' views and demands are not same. Thus, public administration workers of the government should make corresponding decisions in allusion to citizens’ demand.

\section{Conclusion}

The countries in transition are challenged in society and economy. Once national economic form alters to market economy, government's work must be reformed correspondingly. Public administration work with service nature is faced with great reform in the transition period. Clear understanding of reform development tendency can help public administration ensure the efficiency and accuracy of handling affairs and making decisions, give play to its democracy and make corresponding contributions to handling public affairs of countries in transition.

\section{References}

[1] Sun Guoliang, On development tendency of Chinese administration reform. Youth and Society, 2013(31):221-222.

[2] Huang Jian, On evolution and development tendency of public administration - investigation based on diversified approaches. Journal of Tianzhong, 2013,28(5):24-28.

[3] Miao Yuexia, Wang Shan, Innovation and development of Asian public administration reform summary of views in Asian public administration reform seminar. Chinese Public Administration, 2011(9):126-128.

[4] Zhu Qianwei, Bureaucratization, de-bureaucratization and their balance: understanding of western public administration reform. Chinese Public Administration, 2010(4):47-50.

[5] Sun Zhihui, Bai Yunzhen, Public administration reform of countries in transition: Comparative study on China and Russia. Review of Economic Research, 2014(27):11-20. 